\title{
Return of results in translational iPS cell research: considerations for donor informed consent
}

\author{
Geoffrey P Lomax* and Kelly A Shepard*
}

\begin{abstract}
Efforts have emerged internationally to recruit donors with specific disease indications and to derive induced pluripotent cell lines. These disease-specific induced pluripotent stem cell lines have the potential to accelerate translational goals such as drug discovery and testing. One consideration for donor recruitment and informed consent is the possibility that research will result in findings that are clinically relevant to the cell donor. Management protocols for such findings should be developed a priori and disclosed during the informed consent process. The California Institute for Regenerative Medicine has developed recommendations for informing donors in sponsored research. These recommendations include obtaining consent to recontact tissue donors for a range of scientific, medical and ethical considerations. This article reviews the basis for these recommendations and suggests conditions that may be appropriate when reporting findings to donors.
\end{abstract}

\section{Introduction}

Induced pluripotent stem (iPS) cells and their derivatives support translational medicine applications [1]. Efforts have emerged internationally to recruit donors with specific disease indications and to derive new iPS cell lines. These disease-specific iPS cell lines can be differentiated into cells that were previously inaccessible, such as human brain and heart cells, while carrying the genetic background of the patient with a specific disorder. Disease-specific lines have the potential to accelerate translational goals such as drug discovery and testing.

One consideration for donor recruitment and informed consent is the possibility that research will result in findings that are clinically relevant to the cell donor. A robust consent process should acknowledge that derived

*Correspondence: glomax@cirm.ca.gov; kshepard@cirm.ca.gov 210 King Street, San Francisco, CA 94107, USA cells will be used in a range of basic and translational research applications [2]. By extension, there is an imperative to consider the management of research findings a priori and to disclose options in the informed consent process. This article reports on the California Institute for Regenerative Medicine (CIRM) guidance for informed consent and the management of research findings in the context of an institute-sponsored initiative to recruit disease-specific donors for the derivation of new iPS cell lines.

\section{CIRM iPS Cell Initiative}

The CIRM iPS Cell Initiative is designed to ensure the availability of high-quality lines for disease modeling, target discovery and drug screening and development [3]. CIRM is pursuing prevalent, genetically complex conditions with significant potential for impacting our understanding of disease mechanisms and for improving treatment options for patient populations. The CIRM iPS Cell Initiative will result in the derivation and subsequent distribution of lines from an estimated 3,000 individual somatic cell donors.

\section{Repository research system}

The CIRM iPS Cell Initiative employs a repository research system model where donor tissue samples originate at collection sites (see Figure 1). Samples are used to generate iPS cell lines, which are then deposited in the repository for curation and subsequent distribution to secondary researchers [4].

In biological repository research systems, policy debate has focused on the management of individual findings that may arise from secondary research and have clinical relevance to the original cell donors. Attention has been given to findings emerging from genetic studies where sequencing identifies a disease or risk of disease specific to the cell donor. Guidelines for reporting results are suggested and typically describe a set of conditions that would warrant the communication of findings $[4,5]$. It is anticipated that iPS cells deposited in the CIRMsponsored repository will be subject to genomic analysis. However, for reasons discussed below, subsequent findings may have certain limitations. 


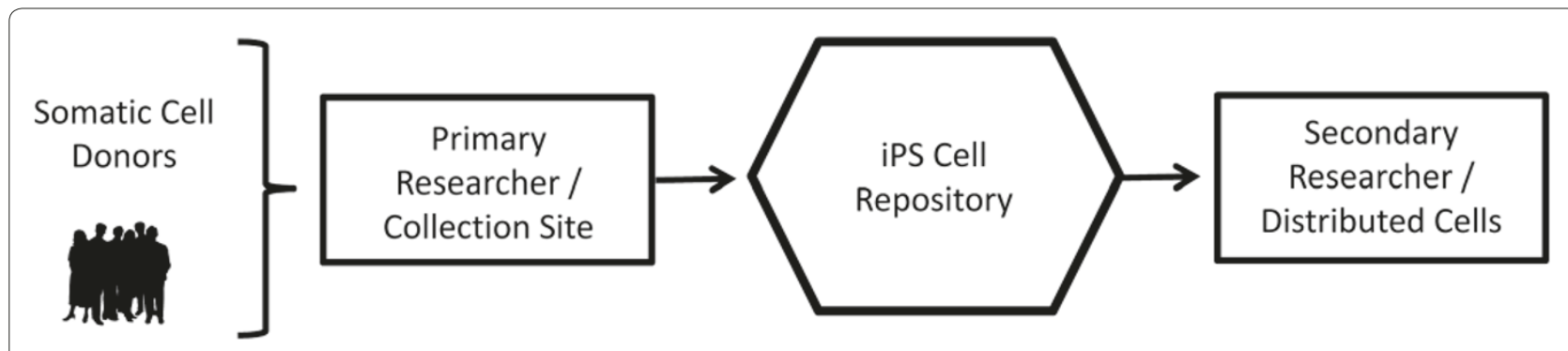

Figure 1. Biological repository research system. iPS, induced pluripotent stem. Adapted with permission from [4].

\section{Current management approaches}

Johnson and colleagues examined the management of individual findings in repositories where donors' samples are subject to genomic analysis [6]. The majority of repositories in their sample did not address the return of incidental research results or findings. Forty-three National Institute of Health intramural repositories were evaluated, and no repository 'stated specifically it would return incidental research results' [6]. Among 19 other US and non-US repositories, three (15\%) stated specifically that they would return incidental findings. Two of these were providers that market personalized medical services. Few, if any, existing research repository systems therefore have explicit policies for returning individual findings.

The National Bioethics Advisory Commission presumes that the disclosure of individual research results to participants represents an exceptional circumstance, and should only occur if the findings are scientifically valid and confirmed, if the findings have significant implications for the subject's health concerns, and if a course of action to ameliorate or treat these concerns is readily available [7].

At this time, there appears to be a limited set of genetic findings that satisfy the National Bioethics Advisory Commission criteria. Green and colleagues explored specific conditions that may be identified through wholegenome sequencing and surveyed specialists in clinical genetics to determine whether they would recommend disclosure. There were 21 conditions or genes in which all 16 specialists agreed that known pathogenic mutations should be disclosed if found incidentally in adults [8].

\section{Scientific and ethical considerations for iPS cell research}

CIRM considered the management of individual findings while drafting a model informed consent document for the CIRM iPS Cell Initiative. The evaluation was conducted in consultation with CIRM's Scientific and Medical Accountability Standards Working Group. This working group comprises scientists, patient advocates, ethicists and clinicians, and its charge includes recommending 'ethical procedures for obtaining cells for research' [9]. The evaluation process involved examining recruitment and consent protocols for iPS cell derivation, a literature review, and testimonials from primary researchers collecting specimens, organizations operating biological repositories, secondary researchers and patient donors. Working group deliberations and follow-up research produced the following conclusions.

\section{iPS cell derivation can introduce unknown changes to donor cells}

The iPS cell derivation process can introduce unknown changes to the donor cells. Existing guidelines focus on a repository research system where biological specimens, biomarkers and/or associated data correlate with the donor's native genotype at the time of sample collection. For example, a blood sample in a research repository may have identical genetic characteristics to a sample that would be collected for a diagnostic test.

The degree to which the iPS cell genotype differs from that of the original tissue donor is not fully understood. iPS cells have demonstrated significant genetic variability upon reprogramming and subsequent culture. While some of this variability may be attributed to pre-existing differences among somatic cells within the donor [10], a number of additional factors have been identified that can influence this property - including the introduction of somatic cell coding mutations [11] and of changes to the allelic copy number [12] during reprogramming and cell culture. To what extent this variability could be ameliorated is not yet clear.

The behavior and phenotype of iPS cells and their derivatives in the research setting may also reflect epigenetic changes and other forms of variability that can be introduced during the reprogramming process [1317]. While many such alterations would be represented in the underlying genetic code, there remains a theoretical possibility that future research on reprogrammed cells will identify nongenetic correlates that would be of interest as an incidental finding. 
No protocols exist to harmonize results from research utilizing iPS cell lines

Protocols do not exist to harmonize results from research laboratories utilizing iPS cell lines, with clinical (Clinical Laboratory Improvement Amendments-approved) laboratories necessary to validate findings.

The CIRM iPS Cell Initiative will operate in a jurisdiction governed by the Clinical Laboratory Improvement Amendments. These regulations impose a number of quality assurance requirements designed to ensure the analytical validity of a particular assay. No protocols exist currently to validate findings derived from iPS cells.

\section{Incidental findings of complex disease are difficult to interpret}

Incidental findings of a complex trait or disease are difficult to interpret. There is broad acknowledgement that returning findings to a patient constitutes an exceptional circumstance that warrants special consideration. The National Heart Lung and Blood Institute Working Group on Reporting Genetic Results in Research Studies has suggested a decision-making framework for such a circumstance that takes into account relative disease risk and penetrance [5,18]. This framework is designed to make a determination of whether some type of efficacious clinical or lifestyle intervention (actionable) is available.

With the CIRM iPS Cell Initiative there may be incidental findings related to the targeted disease or an undiagnosed complex condition. Polygenic diseases are multifactorial, resulting from a poorly understood confluence of pleiotropic gene effects and often the environmental history to which a cell or individual has been exposed. Methodologies for the quantification of relative risk and penetrance for such disorders are limited and generally have not been sufficiently validated.

\section{Suggesting individual results may propagate therapeutic misconception}

Suggesting that individual results may emerge can propagate a therapeutic misconception. Obtaining consent to return findings is an essential prerequisite to providing individual research results. However, obtaining consent for the return of findings may contribute to a therapeutic misconception [19]. Researchers implementing iPS cell derivation protocols involving donors with polygenic neurologic disease cited examples suggesting that a therapeutic misconception may persist with some donors despite a comprehensive consent process [20].

\section{Researchers have different obligations}

Physicians have different obligations to patients than researchers have to donors. Findings will occur in secondary research laboratories utilizing cells provided by the bank. These laboratories will have no relationship with the cell donors. The purpose of the CIRM iPS Cell Initiative is to support research designed to create generalizable knowledge to help patient populations in the future. Obligations of researchers to donors whose cell derivatives they study are fundamentally different from contexts where there is a direct relationship with patients. The obligation to offer results does not necessarily extend to investigators or scientists who have no clinical relationship with the patient. Further, imposing such an obligation may result in liability to the researcher $[21,22]$.

\section{Considerations for translational research}

Discussions regarding the management of research findings have focused on individual results arising from genomic studies. Translational studies are generally designed to develop therapeutic opportunities with clinical utility to a disease population. For example, one objective of the CIRM iPS Cell Initiative is the development of screens to identify potential therapeutics or drug toxicities. If a therapeutic benefit is identified, then this information may be valuable to the population with disease.

There is consensus that beneficial research results should be disseminated to participants and others who stand to benefit from the intervention [6]. There is also a strong desire among participants and the public to receive research results [23]. Unlike genomic findings that may be specific to the individual donor, clinically relevant or actionable results from iPS cell research generally can be disseminated without identifying the individual donors because they would hold for all persons with the condition, not just the source of the iPS cell line. Readily available dissemination mechanisms - internet postings, journal articles, and press reports - may be utilized. A repository may go further and develop a mechanism to actively alert researchers or clinicians at the collection site to new findings without the need to associate the results with specific donors.

iPS cells may become widely distributed, perhaps indefinitely, and may be the basis for translational medicine applications. One question that cannot be resolved now is whether conditions might exist in the future where a secondary researcher feels compelled to communicate findings to donors or their caregivers. For example, use of iPS cells as a screening tool may reveal an adverse drug reaction in a subpopulation. If cell donors were recruited based on this disease indication, then they may have immediate benefit from the research findings. Given this potential for benefit, CIRM believes that leaving open the possibility of recontacting individual donors is appropriate, and the informed consent process should acknowledge this contingency. 


\section{CIRM recommendation}

Based on the aforementioned scientific and ethical considerations research, CIRM excluded specific language regarding incidental genetic findings. However, CIRM did seek to develop language it believes is scientifically and ethically appropriate in the context of the iPS Cell Initiative. The specific language is designed to limit the potential for therapeutic misconception and to avoid creating a duty to return incidental findings. Authors suggest such a duty could create legal obligations and financial risks that exceed clinical standards [21,22].

The CIRM model consent form includes the following statement:

In the future, we may want to contact you to (1) obtain additional samples or updates on your health or (2) inform you about significant new findings that may impact you, or (3) to get your permission for research not covered in this consent form.

(Original emphasis)

Model informed consent for CIRM RFA 12-02: CIRM Tissue Collection for Disease Modeling Awards http://www.cirm.ca.gov/files/grants/pdf/Appendix_A.pdf

The model language is consistent with the model suggested by Lowenthal and colleagues [2]. Arguably, the potential for therapeutic misconception is not completely alleviated. The model language is also nonbinding because the precise wording is ultimately protocol dependent and the responsibility of the primary collection site and institutional review board. Combined with a robust informed consent process, this language may appropriately reflect the research potential of iPS cells at this time.

\section{Discussion}

The purpose of the CIRM iPS Cell Initiative is to advance research and therapy development. This purpose is emphasized in the consent process and donors are informed that participation is not intended to provide direct medical benefit. There is, however, an a priori desire to obtain consent to recontact tissue donors for a range of scientific and ethical considerations - to obtain health updates, to inform the donor of new findings, or to obtain additional consent. Given the many uses of iPS cell lines and the desire to contact donors for multiple reasons, it seems appropriate to leave open the possibility of returning findings. Conversely, there should be no promise or expectation that findings will be provided because re-contact may not be feasible. As noted above, management practices are protocol dependent and the responsibility of the primary collection site and institutional review board.
The CIRM recommendations are based on the assumption that secondary researchers will utilize iPS cell lines in translational studies. These recommendations are not intended in settings where iPS cell research is taking place with patients alongside their clinical care. For example, some iPS cell research is conducted in a primary care setting where donors routinely interact with clinicians at the collection site. In this context, where a physicianpatient or researcher-donor relationship exists, the return of individual incidental findings, if consented, occurs in a clinical care setting. There is a fundamental duty to serve the patient in this setting. Further, the clinical environment is conducive to the communication of findings and the initiation of follow-up interventions.

\section{Conclusion}

CIRM encourages active dissemination of generalizable knowledge gained from institute-funded research, particularly if a population health benefit is identified. In the context of the CIRM iPS Cell Initiative, the weight of evidence suggests that criteria supporting the return of individual genomic findings are not met. Given the potential for iPS cells to support translational research, one should not preclude the ability to recontact donors. Based on this reasoning, the consent form does disclose that the identification of significant new findings may be the basis for recontact. CIRM intends to evaluate the efficacy of this approach to inform ongoing research efforts.

This article is part of a thematic series on Clinical applications of stem cells edited by Mahendra Rao. Other articles in the series can be found online at http://stemcellres.com/series/clinical

Abbreviations

CIRM, California Institute for Regenerative Medicine; iPS, induced pluripotent stem.

\section{Competing interests}

The authors declare that they have no competing interests.

Published: 21 January 2013

\section{References}

1. Trounson A, Shepard KA, Dewitt ND: Human disease modeling with induced pluripotent stem cells. Curr Opin Genet Dev 2012, 22:509-516.

2. Lowenthal J, Lipnick S, Rao M, Hull S: Specimen collection for induced pluripotent stem cell research: harmonizing the approach to informed consent. Stem Cells Trans/ Med 2012, 1:409-421.

3. RFA 12-04: CIRM hPSC Repository Award [http://www.cirm.ca.gov/RFA/rfa-12-04-cirm-hpsc-repository-award]

4. Crock BN, Van Ness B, Lawrenz F, Kahn JP, Beskow LM, Cho MK, Christman MF, Green RC, Hall R, Illes J, Keane M, Knoppers BM, Koenig BA, Kohane IS, Leroy B, Maschke K.J, McGeveran W, Ossorio P, Parker LS, Petersen GM, Richardson HS, Scott JA, Terry SF, Wilfond BS, WolfWA: Managing incidental findings and research results in genomic research involving biobanks and archived data sets. Genet Med 2012, 14:361-384.

5. Fabsitz RR, McGuire A, Sharp RR, Puggal M, Beskow LM, Biesecker LG, Bookman E, Burke W, Burchard EG, Church G, Clayton EW, Eckfeldt JH, Fernandez CV, Fisher R, Fullerton SM, Gabriel S, Gachupin F, James C, Jarvik 
GP, Kittles R, Leib, JR, O'Donnell C, O'Rourke P P, Rodriguez LL, Schully SD, Shuldiner AR, Sze RK, Thakuria JV, Wolf SM, Burke GL: Ethical and practical guidelines for reporting genetic research results to study participants: updated guidelines from a National Heart, Lung, and Blood Institute working group. Circ Cardiovasc Genet 2010, 3:574-580

6. Johnson G, Lawrenz F, Thao M: An empirical examination of the management of return of individual research results and incidental findings in genomic biobanks. Genet Med 2012, 14:444-450.

7. National Bioethics Advisory Comission: Research Involving Human Biological Materials: Ethical Issues and Policy Guidance: Volume 1. Bethesda, MD: National Bioethics Advisory Commission; 1999. http://bioethics.georgetown.edu/nbac/pubs.html (accessed 11/14/12)

8. Green RC, Berg JS, Berry GT, Biesecker LG, Dimmock DP, Evans J P, Grody WW Hegde MR, Kalia S, Korf BR, Krantz I, McGuire AL, Miller DT, Murray MF, Nussbaum RL, Plon SE, Rehm HL, Jacob HJ: Exploring concordance and discordance for return of incidental findings from clinical sequencing. Genet Med 2012, 14:405-410.

9. The California Stem Cell Research and Cures Initiative 2004 (Proposition 71). http://www.cirm.ca.gov/files/PDFs/Administrative/prop71-3.pdf (accessed 11/14/12)

10. Young MA, Larson DE, Sun CW, George DR, Ding L, Miller CA, Lin L, Pawlik KM, Chen K, Fan X, Schmidt H, Kalicki-Veizer J, Cook LL, Swift GW, Demeter RT, Wendl MC, Sands MS, Mardis ER, Wilson RK, Townes TM, Ley TJ: Background mutations in parental cells account for most of the genetic heterogeneity of induced pluripotent stem cells. Cell Stem Cell 2012, 10:570-582.

11. Gore A, Li Z, Fung HL, Young JE, Agarwal S, Antosiewicz-Bourget J, Canto I, Giorgetti A. Israel MA, Kiskinis E, Lee JH, Loh YH, Manos PD, Montserrat N, Panopoulos AD, Ruiz S, Wilbert ML, Yu J, Kirkness EF, Izpisua Belmonte JC, Rossi DJ, Thomson JA, Eggan K, Daley GQ, Goldstein LS, Zhang K: Somatic coding mutations in human induced pluripotent stem cells. Nature 2011, 471:63-67.

12. Laurent LC, Ulitsky I, Slavin I, Tran H, Schork A, Morey R, Lynch C, Harness JV, Lee S, Barrero MJ, Ku S, Martynova M, Semechkin R, Galat V, Gottesfeld J, Izpisua Belmonte JC, Murry C, Keirstead HS, Park HS, Schmidt U, Laslett AL, Muller FJ, Nievergelt CM, Shamir R, Loring JF: Dynamic changes in the copy number of pluripotency and cell proliferation genes in human ESCs and iPSCs during reprogramming and time in culture. Cell Stem Cell 2011, 8:106-118.

13. Marchetto MC, Yeo GW, Kainohana O, Marsala M, Gage FH, Muotri AR: Transcriptional signature and memory retention of human-induced pluripotent stem cells. PLoS One 2009, 4:e7076.

14. Ohi Y, Qin H, Hong C, Blouin L, Polo JM, Guo T, Qi Z, Downey SL, Manos PD, Rossi DJ, Yu J, Hebrok M, Hochedlinger K, Costello JF, Song JS,
Ramalho-Santos M: Incomplete DNA methylation underlies a transcriptional memory of somatic cells in human iPS cells. Nat Cell Biol 2011, 13:541-549.

15. Lister R, Pelizzola M, Kida YS, Hawkins RD, Nery JR, Hon G, AntosiewiczBourget J, O'Malley R, Castanon R, Klugman S, Downes M, Yu R, Stewart R, Ren $B$, Thomson JA, Evans RM,Ecker JR: Hotspots of aberrant epigenomic reprogramming in human induced pluripotent stem cells. Nature 2011, 471:68-73.

16. Mekhoubad S, Bock C, de Boer A S, Kiskinis E, Meissner A, Eggan K: Erosion of dosage compensation impacts human iPSC disease modeling. Cell Stem Cell 2012, 10:595-609.

17. Nazor KL, Altun G, Lynch C, Tran H, Harness JV, Slavin I, Garitaonandia I, Muller FJ, Wang YC, Boscolo FS, Fakunle E, Dumevska B, Lee S, Park HS, Olee T, D'Lima DD, Semechkin R, Parast MM, Galat V, Laslett AL, Schmidt U, Keirstead HS, Loring JF, Laurent LC: Recurrent variations in DNA methylation in human pluripotent stem cells and their differentiated derivatives. Cell Stem Cell 2012, 10:620-634.

18. Bookman EB, Langehorne AA, Eckfeldt JH, Glass KC, Jarvik GP, Klag M, Koski G, Motulsky A, Wilfond B, Manolio TA, Fabsitz RR, Luepker RV: Reporting genetic results in research studies: summary and recommendations of an NHLBI working group. Am J Med Genet A 2006, 140:1033-1040.

19. Evans JP, Rothschild BB: Return of results: not that complicated? Genet Med 2012, 14:358-360.

20. Scientific and Medical Accountablity Standards Working Group Regular Meeting [http://www.cirm.ca.gov/files/transcripts/pdf/2012/040612_transcript.pdf

21. Clayton EW, McGuire AL: The legal risks of returning results of genomics research. Genet Med 2012, 14:473-477.

22. Bledsoe MJ, Grizzle WE, Clark BJ, Zeps N: Practical implementation issues and challenges for biobanks in the return of individual research results. Genet Med 2012, 14:478-483.

23. Bollinger JM, Scott J, Dvoskin R, Kaufman D: Public preferences regarding the return of individual genetic research results: findings from a qualitative focus group study. Genet Med 2012, 14:451-457.

doi:10.1186/scrt154

Cite this article as: Lomax GP, Shepard KA: Return of results in translational iPS cell research: considerations for donor informed consent. Stem Cell Research \& Therapy 2013, 4:6. 